\title{
ANALISIS PENGARUH PENAMBAHAN SIKAMENT-NN TERHADAP KARAKTERISTIK BETON
}

\author{
Shanti Wahyuni Megasari \\ Program Studi Teknik Sipil Universitas Lancang Kuning \\ Jalan Yos Sudarso Km. 8 Rumbai Pekanbaru \\ E-mail : shanti@unilak.ac.id \\ Winayati \\ Program Studi Teknik Sipil Universitas Lancang Kuning \\ Jalan Yos Sudarso Km. 8 Rumbai Pekanbaru \\ E-mail : winayatimt@gmail.com
}

\begin{abstract}
Abstrak
Beton ready mix merupakan solusi dalam pengadukan beton dengan kapasitas besar, namun penggunaan beton ready mix di lapangan sering mengalami beberapa kendala terkait waktu perjalanan ke lokasi yang tidak lancar dan kebutuhan akan mempercepat pengerasan beton setelah dituang. Untuk mengatasi masalah tersebut, kemajuan teknologi beton telah menghasilkan bahan tambah (admixture) yang dapat membantu dalam menjaga kualitas dan kelecakan (workabilty) beton. Salah satu produk keluaran dari PT. Sika Indonesia adalah Sikament-NN. Sikament-NN merupakan superplasticizer untuk membantu menghasilkan kekuatan awal dan kekuatan akhir tinggi. Tujuan penelitian adalah untuk menganalisis pengaruh variasi persentase bahan tambah Sikament-NN terhadap karakteristik kuat tekan beton. Perancangan beton menggunakan metode Department of Environment (DOE) dengan cetakan sampel berbentuk silinder ukuran diameter $150 \mathrm{~mm}$ dan tinggi $300 \mathrm{~mm}$. Persentase penambahan Sikament-NN sebanyak 0\%, 0,3\%, 0,8\%, 1,3\%, 1,8\%, 2,3\%. Pengujian kuat tekan beton dilaksanakan pada umur 28 hari. Hasil pengujian menunjukkan bahwa kecenderungan (trend) grafik kuat tekan rata-rata mengalami peningkatan dengan penambahan persentase Sikament-NN sebesar 1,3\% dan 1,8\%. Persamaan yang dihasilkan dari kuat tekan rata-rata adalah $y=-0,551 x^{2}+6,791 x+23,81$. Nilai kuat tekan rata-rata tertinggi diperoleh pada penambahan 1,8\% Sikament-NN yaitu sebesar 38,65 MPa. Pengujian statistik dengan menggunakan analisis varians (Analysis of Variance - ANOVA) menyatakan bahwa terdapat interaksi atau perlakuan yang sangat nyata antara kuat tekan beton dengan penambahan Sikament-NN. Sehingga dapat disimpulkan bahwa penambahan Sikament-NN berpengaruh terhadap peningkatan karakteristik kuat tekan beton.
\end{abstract}

Kata Kunci : Anova, Beton, Kuat Tekan, Pengaruh, Sikament-VZ 


\begin{abstract}
Ready mix concrete is a solution in large capacity concrete mixing, but the use of ready mix concrete in the field often has some constraints related to the time of travel to the noncurrent location and the need to accelerate the hardening of concrete after being poured. To overcome these problems, the advancement of concrete technology has resulted in additional materials (admixture) that can help in maintaining the quality and concrete (workabilty) of concrete. One product output from PT. Sika Indonesia is Sikament-NN. Sikament-NN is a superplasticizer to help produce initial strength and high end strength. The purpose of this research is to analyze the influence of percentage variation of Sikament-NN to concrete compressive strength characteristic. Concrete design using Department of Environment (DOE) method with cylindrical sample mold, diameter $150 \mathrm{~mm}$ and height $300 \mathrm{~mm}$. The percentage of Sikament-NN addition is $0 \%$, $0,3 \%, 0,8 \%, 1,3 \%, 1,8 \%, 2,3 \%$. Testing of concrete compressive strength is carried out at the age of 28 days. The test results showed that the trend of the average compressive strength graph increased with the addition of Sikament-NN percentage of 1,3\% and $1,8 \%$. The equation resulting from the average compressive strength is $y=-0,551 x^{2}+$ $6,791 x+23,81$. The highest average compressive strength value was obtained in the addition of 1,8\% Sikament-NN which is 38,65 MPa. Statistical testing by using Analysis of Variance - ANOVA states that there is a very real interaction or treatment between the compressive strength of concrete with the addition of Sikament-NN. So it can be concluded that the addition of Sikament-NN effect on the increase of concrete compressive strength characteristics.
\end{abstract}

Keywords : Anova, Concrete, Compressive Strength, Influence, Plastiment-VZ.

\section{A. PENDAHULUAN}

Pada pembangunan konstruksi dalam skala besar atau massal, pelaksanaan pekerjaan pencampuran dan pengadukan beton jarang dilakukan secara manual atau dengan menggunakan mesin pengaduk (molen) kapasitas kecil. Karena hal tersebut kurang efisien dari segi waktu, jumlah tenaga kerja dan biaya. Oleh karena itu perkembangan teknologi beton sudah mulai beralih pada beton ready mix.

Namun penggunaan beton ready mix di lapangan sering mengalami beberapa kendala, antara lain jarak tempuh yang cukup jauh antara batching plant dengan lokasi proyek, kondisi jalan yang rusak dan kemacetan yang tidak bisa diprediksi, waktu tunggu antara pembongkaran mobil ready mix satu dengan berikutnya dan faktorfaktor lainnya. Waktu tunggu yang terbuang tidak bisa diprediksi dengan tepat, karena tergantung pada faktor yang mempengaruhinya tadi. Bahkan waktu tunggu di lapangan bisa mencapai lebih dari 60 menit (1 jam), selama menunggu tersebut mobil ready mix harus selalu berputar sehingga beton tidak mengeras. Apabila kondisi tersebut tidak diatasi maka akan mempengaruhi kualitas, kelecakan (workabilty) beton serta kondisi beton yang tidak maksimal. Apabila mutu beton yang dihasilkan tidak memenuhi kekuatan tekan rencana maka akan berakibat pada perubahan data perencanaan, perubahan pembebanan yang mampu dipikul struktur, perkuatan struktur, pembongkaran hingga perubahan fungsi bangunan.

Namun ketika mobil ready mix telah sampai di lokasi proyek dan beton selesai dituang pada cetakan maka pada 
beberapa pekerjaan dibutuhkan kebalikan dari kondisi sebelumnya. Jika diperjalanan diperlukan agar kondisi beton selalu encer atau kelecakan (workabilty) tinggi, maka setelah beton dituang maka diperlukan beton agar dapat segera mengeras untuk mempercepat proses pekerjaan di lapangan. Hal yang berlawanan tersebut tentu saja mengakibatkan kesulitan dalam pelaksanaan pekerjaan sehingga diperlukan perlakuan khusus dalam penanganannya.

Untuk mengatasi masalah tersebut, kemajuan teknologi beton telah menghasilkan bahan tambah (admixture) yang dapat membantu dalam menjaga kualitas dan kelecakan (workabilty) beton serta mempercepat pengerasan. Salah satu produk keluaran dari PT. Sika Indonesia adalah Sikament-NN, Sikament-NN merupakan superplasticizer yang sangat efektif dalam mengurangi jumlah air beton untuk membantu menghasilkan kekuatan awal dan kekuatan akhir tinggi.

Namun untuk penggunaan di lapangan, pemilihan bahan tambah harus disesuaikan dengan situasi dan kondisi beton yang telah direncanakan. Pemakaian bahan tambah yang berlebihan juga akan mengakibatkan beton tidak ekonomis, mengingat harga dari suatu bahan tambah sangat mahal.

Pada Data Teknis PT. Sika Indonesia (2011), dosis yang harus diberikan untuk penggunaan SikamentNN diantara $0,30 \%-2,30 \%$ terhadap berat semen tergantung pada kelecakan dan kuat tekan beton yang diinginkan. Kondisi tersebut tentu saja mempersulit masyarakat baik penyedia jasa dan pengguna jasa konstruksi khususnya di Kota Pekanbaru karena belum diketahui dengan jelas dosis atau takaran yang sesuai dengan kondisi material baik semen maupun agregat yang tersedia di
Kota Pekanbaru, apalagi jika dilakukan kombinasi antara kedua bahan tersebut.

Sehingga untuk mendapatkan hasil maksimal yang dapat diaplikasikan secara luas oleh masyarakat baik penyedia jasa dan pengguna jasa konstruksi di Kota Pekanbaru, akan dibutuhkan penelitian untuk dapat mengukur kemampuan beton yang dihasilkan melalui pengujian karakteristik kuat tekan beton dengan variasi kombinasi persentase bahan tambah Sikament-NN dan pengaruh penambahan Sikament-NN terhadap karakteristik beton.

\section{B. TINJAUAN PUSTAKA}

\section{Bahan Tambah (Admixture)}

Berdasarkan Nugraha, P. dan Antoni, (2007), admixture adalah material selain air, agregat dan semen hidrolik yang dicampur dalam beton atau mortar yang ditambahkan sebelum atau selama pengadukan berlangsung.

Penambahan bahan tambah dalam sebuah campuran beton atau mortar tidak mengubah komposisi yang besar dari bahan lainnya, karena penggunaan bahan tambah ini cenderung merupakan pengganti atau substitusi dari dalam campuran beton itu sendiri. Karena tujuannya memperbaiki atau mengubah sifat dan karakteristik tertentu dari beton atau mortar yang dihasilkan, maka kecendrungan perubahan komposisi dalam berat volume tidak terasa langsung dibandingkan dengan komposisi awal beton tanpa bahan tambah.

Secara umum bahan tambah yang digunakan dalam beton dapat dibedakan menjadi dua yaitu bahan tambah yang besifat kimiawi (chemical admixture) dan bahan tambah yang bersifat mineral (additive).

Menurut Aprilianti, S. dan Nadia (2012), untuk menghasilkan beton 
dengan fas rendah namun tetap mudah dikerjakan maka dibutuhkan bahan tambah, salah satunya adalah menggunakan admixture superplasticizer. Dengan kemampuan mengurangi penggunaan air yang tinggi, campuran beton dengan bahan tambah mampu menghasilkan kuat tekan beton yang lebih tinggi.

\section{Sikament-NN}

Menurut Data Teknis PT. Sika Indonesia (2011), Sikament-NN merupakan superplasticizer dengan pengurang air dalam jumlah besar dan mempercepat pengerasan beton. Cairan superplasticizer yang sangat efektif dengan aksi ganda untuk produksi beton yang mengalir atau bahan untuk mengurangi air beton untuk membantu menghasilkan kekuatan awal dan kekuatan akhir tinggi sesuai dengan ASTM C 494-92 type F.

Sikament-NN digunakan sebagai superplasticizer dalam produksi beton yang mengalir dan sebagai bahan pengurang air untuk beton dengan kekuatan awal yang tinggi untuk :

a. Beton pra-cetak

b. Beton pra-tekan

c. Jembatan dan struktur penyangga

d. Area dimana cetakan atau bekisting harus cepat dipindahkan atau segera dibebani

Sikament-NN memberikan keuntungan sebagai berikut :

a. Sebagai superplasticizer

1). Kelecakan (workability) meningkat tajam, memudahkan pengecoran untuk struktur ramping dengan penulangan yang rapat

2). Mengurangi jumlah getaran yang dibutuhkan, waktu pengerasan normal tanpa perlambatan (retardation)
3).Mengurangi resiko pemisahan (segregation) secara signifikan

b. Sebagai bahan pengurang air

1).Pengurangan air hingga $20 \%$ akan memberikan peningkatan $40 \%$ kuat tekan dalam 28 hari

2). Kekuatan tinggi selama 12 jam

Sikament-NN dapat digunakan dengan dosis $0,30 \%-2,30 \%$ dari berat semen tergantung pada kelecakan dan kuat tekan beton yang diperlukan. Sikament-NN dapat ditambahkan ke air adukan sebelum air tersebut dicampurkan dengan agregat atau dalam sebagian kasus ditambahkan langsung ke dalam beton yang baru di aduk. Ketika ditambahkan ke beton yang baru saja diaduk, efek plastizing-nya lebih terlihat. Untuk beton ready mix, Sikament-NN ditambahkan ke beton segera sebelum dituang (discharge) dan setelah pengadukan lebih lanjut selama tiga sampai lima menit. Karakteristik dari Sikament-NN dapat dilihat pada tabel 1 .

Menurut Ramadhani, KC., Yanti, G. dan Winayati (2016), terkait nilai kuat tekan beton dengan menggunakan bahan tambahan Sikament-NN. Dengan kuat tekan rencana campuran untuk beton K-300, dengan variasi persentase dari berat semen yaitu $0 \%, 0,3 \%, 0,8 \%$, $1,3 \%, 1,8 \%, 2,3 \%$. Berdasarkan hasil pengujian yang telah dilakukan diperoleh hasil uji tekan pada persentase Sikament-NN sebesar 1,3\% adalah 590 $\mathrm{kg} / \mathrm{cm}^{2}$. Sedangkan nilai kuat tekan beton tanpa penambahan Sikament-NN adalah sebesar $334 \mathrm{~kg} / \mathrm{cm}^{2}$, namun pada penambahan persentase yang lebih besar terjadi penurunan nilai kuat tekan yakni pada $1,8 \%=528 \mathrm{Kg} / \mathrm{m}^{2}$ dan $2,3 \%=500$ $\mathrm{Kg} / \mathrm{m}^{2}$. Maka dapat disimpulkan bahwa penambahan Sikament-NN pada campuran dapat meningkatkan kekuatan tekan beton. 
Tabel 1. Karakteristik Sikament-NN

\begin{tabular}{|l|l|}
\hline \multicolumn{2}{|c|}{ Data Teknis } \\
\hline Bentuk & Modifikasi Naphtalene Formaldehyde Sulphonate \\
\hline Warna & Coklat Tua \\
\hline Berat Jenis & $\pm 1,18-1,20 \mathrm{~kg} / \mathrm{ltr}$ \\
\hline Umur dan Penyimpanan & $\begin{array}{l}\text { Minimal 1 tahun apabila disimpan dalam kemasan } \\
\text { asli yang belum dibuka pada tempat yang kering, } \\
\text { sejuk dan teduh }\end{array}$ \\
\hline Kemasan & Drum 240 kg, Bulk 1000 kg \\
\hline
\end{tabular}

(Sumber : PT. Sika Indonesia, 2011)

\section{Analysis of Variance (ANOVA)}

Analysis of variance (ANOVA) adalah salah satu uji hipotesis pada statistika parametrik, untuk melakukan pengujian terhadap interaksi antara dua faktor dalam suatu percobaan dengan membandingkan rata-rata dari lebih dua sampel. ANOVA dikembangkan oleh Ronald Fisher (1918) untuk menganalisis keragaman dari suatu respon dan membagi menjadi bagianbagian yang berhubungan dengan sumber keragaman yang diketahui dan dikaitkan dengan galat acak (random error). Sumber keragaman yang diketahui akan dikaitkan dengan varabel-variabel bebas yaitu faktorfaktor yang dicobakan (perlakuan).

Prosedur analisis varians (Analysis of Variance - ANOVA) menggunakan variabel numerik tunggal (single numerical variable) yang diukur dari sejumlah sampel untuk menguji hipotesis nol dari populasi yang (diperkirakan) memiliki rata-rata hitung (mean) sama. Variabel dimaksud harus berupa variabel kuantitatif. Variabel ini terkadang dinamakan sebagai variabel terikat (dependent variable).

Dalam uji ANOVA, bukti sampel diambil dari setiap populasi yang sedang dikaji. Data-data yang diperoleh dari sampel tersebut digunakan untuk menghitung statistik sampel. Distribusi sampling yang digunakan untuk mengambil keputusan statistik, yakni

menolak atau menerima hipotesis nol (H0), adalah Distribusi F (F Distribution).

\section{DATA DAN ANALISA DATA}

\section{Material Penelitian}

Bahan atau material yang digunakan pada penelitian ini adalah :

a. Semen, semen yang digunakan adalah semen Tipe I (Ordinary Portland Cement / OPC), produksi PT. Semen Padang kemasan $50 \mathrm{~kg}$

b. Agregat kasar, agregat kasar atau batu pecah yang digunakan yaitu agregat kasar yang berasal dari daerah Pangkalan

c. Agregat halus, agregat halus (pasir) yang digunakan adalah pasir yang berasal dari daerah Teratak Buluh.

d. Air, air yang digunakan berasal dari air bersih pada Laboratorium Batching Plant PT. Mekar Abadi Mandiri Jalan Lintas Pekanbaru Duri Km.62

e. Bahan Tambah, bahan tambah yang digunakan adalah Sikament-NN dan Plastiment-VZ produksi PT. Sika Indonesia.

\section{Rancangan Benda Uji}

Penelitian ini dilakukan dengan
cara menganalisis pengaruh
penambahan variasi persentase
Sikament-NN terhadap kuat tekan
beton. Plastiment-VZ ditambahkan pada


saat pengecoran awal yang diasumsikan berguna untuk meningkatkan kelecakan (workability) selama di perjalanan.

Perancangan beton menggunakan metode Departement of Environment (DOE), dengan cetakan selinder dengan ukuran $150 \mathrm{~mm}$ x $300 \mathrm{~mm}$. Kecepatan putar mesin pengaduk (molen) diatur yaitu sekitar 25 putaran per menit. Bila mesin pengaduk sudah berputar normal, bahan-bahan campuran beton dimasukkan kedalam drum pengaduk secara berurut yaitu agregat kasar dan sebagian air, kemudian agregat halus, semen dan sisa sebagian air adukan. Lama waktu memasukkan bahan-bahan tersebut tidak lebih dari 5 menit. Setelah semua material tercampur, waktu pengadukan mulai dihitung dengan menggunakan stopwatch, sesuai dengan lama waktu pengadukan yang telah direncanakan.

Variasi persentase Sikament-NN sesuai dengan penelitian Ramadhani, KC., Yanti, G. dan Winayati (2016).

Awal penelitian dimulai dengan melakukan pengujian pendahuluan pada material, pembuatan benda uji, pengecekan nilai slump, tahapan perawatan (perendaman) selama 28 (dua puluh delapan) hari dan dilaksanakan pengujian tekan. Hasil dari pengujian tekan tersebut dilanjutkan dengan analisis data.

Adapun rincian benda uji dapat dilihat pada tabel 2 .

Tabel 2. Rancangan Benda Uji

\begin{tabular}{|c|c|c|c|c|c|c|c|}
\hline \multirow{2}{*}{ Bahan Tambah } & \multicolumn{7}{|c|}{ Jumlah } \\
\cline { 2 - 8 } & $\mathbf{0}$ & $\mathbf{0 , 3}$ & $\mathbf{0 , 8}$ & $\mathbf{1 , 3}$ & $\mathbf{1 , 8}$ & $\mathbf{2 , 3}$ & Sampel \\
\hline Sikament-NN & 3 & 3 & 3 & 3 & 3 & 3 & 18 \\
\hline
\end{tabular}

\section{Analisis Data Kuat Tekan Beton}

Perhitungan nilai kuat tekan dapat digunakan rumus :

$$
\mathrm{f}_{\mathrm{c}}^{\prime}=\frac{\mathrm{P}_{\max }}{\mathrm{A}_{\mathrm{C}}}
$$

Keterangan :

$\mathrm{f}^{\prime}{ }_{\mathrm{c}}=$ Kuat tekan beton $(\mathrm{MPa})$

$\mathrm{P}_{\max }=$ Beban maksimum $(\mathrm{N})$

$\mathrm{A}_{\mathrm{c}}=$ Luas permukaan $\left(\mathrm{mm}^{2}\right)$

\section{Metode Analisis Data}

Analisis varians (ANOVA) adalah suatu teknik statistik yang memungkinkan kita untuk mengetahui apakah dua atau lebih mean populasi akan bernilai sama dengan menggunakan data dari sampel masingmasing populasi. Analisis varians akan menjadi teknik stastistik yang valid untuk diterapkan dengan menggunakan asumsi-asumsi sebagai berikut :
a. Populasi yang dikaji memiliki distribusi normal.
b. Pengambilan sampel dilakukan secara acak dan setiap sampel independen/ tidak terikat sampel lain.
c. Populasi-populasi di mana nilai sampel-sampel diperoleh memiliki nilai varians populasi sama.

Distribusi perlakuan benda uji dapat dilihat pada tabel 3. Untuk perhitungan $\mathrm{F}_{\text {hitung }}$ dengan menggunakan rumus berikut $\mathrm{L}$

$$
\begin{array}{ll}
\mathrm{F}_{\text {hitung }}=\frac{\mathrm{KT}_{\text {perlakukan }}}{\mathrm{KT}_{\text {percobaam }}} \\
\text { Keterangan : } \\
\mathrm{KT}_{\text {perlakuan }}=\text { Kuadrat tengah } \\
\mathrm{KT}_{\text {perclakuan }} \\
\end{array}
$$


Tabel 3. Distribusi perlakuan

\begin{tabular}{|c|c|c|c|c|c|}
\hline \multirow[b]{2}{*}{ No. } & \multirow{2}{*}{$\begin{array}{c}\% \\
\text { Sikament-NN }\end{array}$} & \multicolumn{4}{|c|}{ Speciment } \\
\hline & & 1 & 2 & 3 & Total \\
\hline 1. & 0 & $\mathrm{Y} 1_{1}$ & $\mathrm{Y} 1_{2}$ & $\mathrm{Y} 1_{3}$ & $\sum_{j-1}^{p} Y_{i j}$ \\
\hline 2. & 0,3 & $\mathrm{Y} 2_{1}$ & $\mathrm{Y} 2_{2}$ & $\mathrm{Y}_{3}$ & $\sum_{j-1}^{p} Y_{i j}$ \\
\hline 3. & 0,8 & $\mathrm{Y} 3_{1}$ & $\mathrm{Y}_{2}$ & $\mathrm{Y}_{3}$ & $\sum_{j-1}^{p} Y_{i j}$ \\
\hline 4. & 1,3 & $\mathrm{Y}_{1}$ & $\mathrm{Y}_{2}$ & $\mathrm{Y}_{3}$ & $\sum_{j-1}^{p} Y_{i j}$ \\
\hline 5. & 1,8 & $\mathrm{Y}_{1}$ & $\mathrm{Y}_{2}$ & $\mathrm{Y}_{3}$ & $\sum_{j-1}^{p} Y_{i j}$ \\
\hline 6. & 2,3 & $\mathrm{Y}_{1}$ & $\mathrm{Y}_{2}$ & $\mathrm{YG}_{3}$ & $\sum_{j-1}^{p} Y_{i j}$ \\
\hline
\end{tabular}

Distribusikan $F$ pada level signifikan $F_{\text {kritis }} \alpha=0,05$ atau 0,01 . Jika $F_{\text {hit }}>F_{\text {tabel }}$ maka terdapat perlakuan yang sangat nyata. Dengan catatan jika $\alpha=0,05$ disebut berbeda atau berpengaruh nyata, dan jika $\alpha=0,01$ disebut berbeda atau berpengaruh sangat nyata. Analisis data hasil uji $F$ dapat dilihat pada tabel 4.

Keterangan :

$$
\begin{aligned}
& \text { SK = Sumber keragaman } \\
& \mathrm{db}=\text { Derajat bebas } \\
& \mathrm{JK}=\text { Jumlah kuadrat } \\
& \mathrm{JK}_{\mathrm{P}}=\mathrm{Jumlah}_{\text {kuadrat }} \text { Perlakuan } \\
& =\sum_{\mathrm{i}-1}^{\mathrm{p}}\left(\sum_{\mathrm{j}-1}^{\mathrm{p}} \mathrm{Y}_{\mathrm{ij}}\right)^{2} / \mathrm{n}-\mathrm{FK} \\
& \mathrm{JK}_{\mathrm{G}}=\mathrm{Jumlah}_{\text {kuadrat }} \text { Galat } \\
& =\mathrm{JK}_{\text {Total }}-\mathrm{JK}_{\text {Perlakuan }}
\end{aligned}
$$

$$
\begin{aligned}
\mathrm{JK}_{\mathrm{T}} & =\text { Jumlah kuadrat Total } \\
& =\sum_{\mathrm{i}-1}^{\mathrm{p}} \sum_{\mathrm{j}-1}^{\mathrm{p}} \mathrm{Y}^{2}{ }_{\mathrm{ij}}-\mathrm{FK} \\
\mathrm{FK} & =\text { Faktor koreksi } \\
& =\left(\sum_{i-1}^{p} \sum_{j-1}^{p} Y_{i j}\right)^{2} / p n \\
\mathrm{KT} & =\text { Kuadrat tengah } \\
\mathrm{KT}_{\mathrm{P}} & =\text { Kuadrat tengah Perlakuan } \\
& =\mathrm{JK}_{\mathrm{P}} /(\mathrm{p}-1) \\
\mathrm{KT}_{\mathrm{G}} & =\mathrm{Kuadrat} \text { tengah } \mathrm{G} . \text { perc } \\
& =\mathrm{JK}_{\mathrm{G}} /(\mathrm{p}(\mathrm{n}-1) \text { untuk } \mathrm{n} \text { sama } \\
& =\mathrm{JK}_{\mathrm{G}} /\left(\Sigma_{\mathrm{i}}\left(\mathrm{n}_{\mathrm{i}}-1\right) \mathrm{n}\right. \text { tidak sama }
\end{aligned}
$$

\section{Bagan Alir Penelitian}

Bagan alir penelitian dapat dilihat pada gambar 1 . 
Tabel 4. Analisis data hasil uji $F$

\begin{tabular}{lcccc}
\multicolumn{1}{c}{ SK } & db & JK & KT & $\mathbf{F}_{\text {hitung }}$ \\
\hline Perlakuan & $(p-1)$ & $n \sum^{P}{ }_{i}(Y-Y . .)^{2}=\mathrm{JK}_{\mathrm{P}}$ & $\mathrm{KT}_{P}$ & \\
Galat Percobaan & $(p n-1)$ & $\sum^{P}{ }_{i} \sum^{n}{ }_{i}\left(Y_{i l}-Y_{i . .}\right)^{2}=\mathrm{JK}_{\mathrm{G}}$ & $\mathrm{KT}_{G}$ & $\mathrm{KT}_{P} / \mathrm{KT}_{G}$ \\
\hline Total & $(p n-1)$ & $\sum^{P}{ }_{i} \sum_{{ }_{i}}^{n_{i}}\left(Y_{i l}-Y_{i . .}\right)^{2}=\mathrm{JK}_{\mathrm{T}}$ & - & - \\
\hline
\end{tabular}

(Sumber : Yitnosumarto, S., 1991)

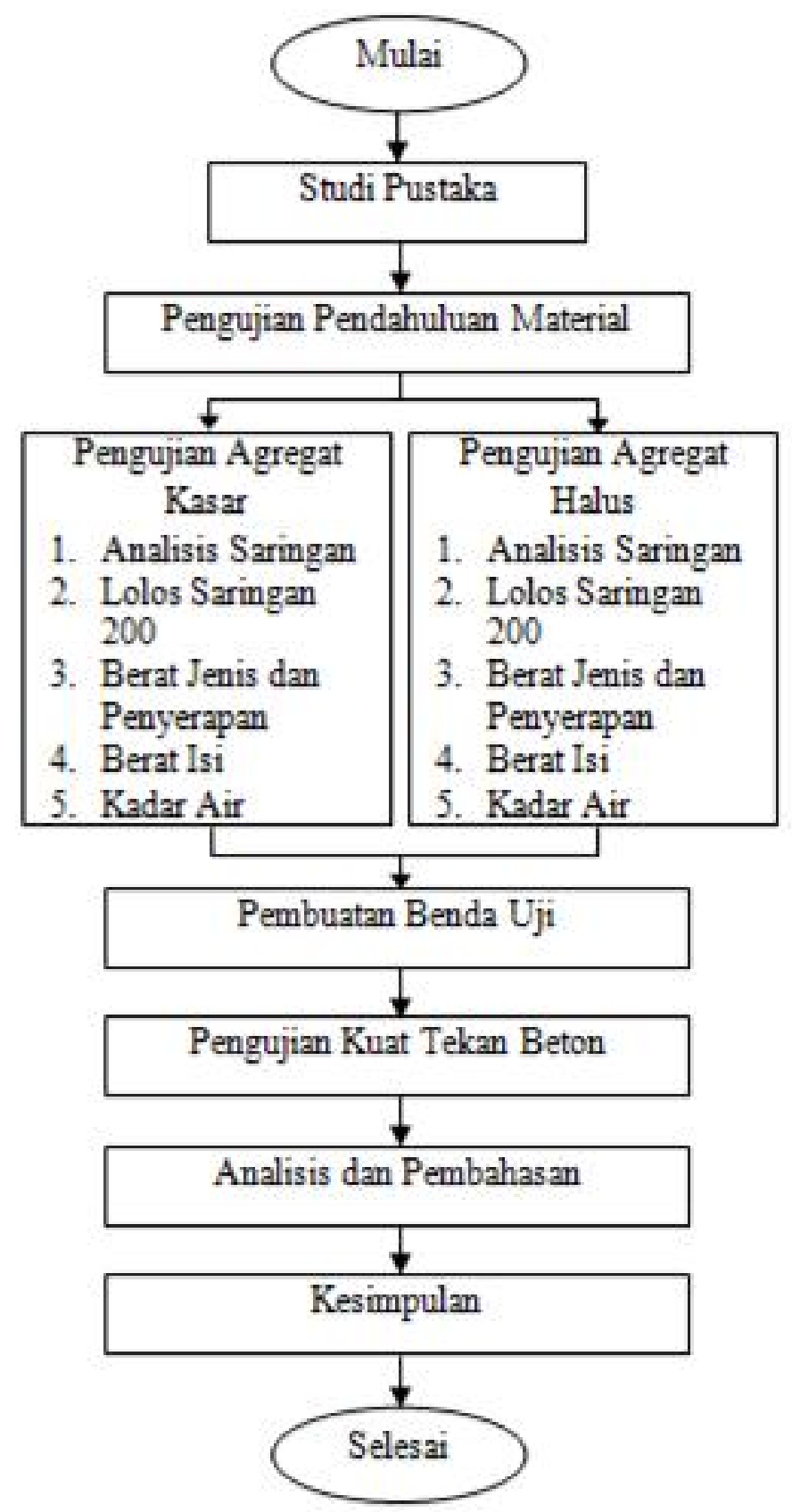

Gambar 1. Bagan Alir Penelitian 
D. HASIL DAN PEMBAHASAN

\section{Hasil Pengujian Kuat Tekan Beton}

Hasil pengujian terhadap benda uji menunjukkan bahwa terjadi peningkatan nilai kuat tekan beton dengan penambahan Sikament-NN sebesar $1,3 \%$ dan $1,8 \%$.

Hasil pengujian kuat tekan benda uji dengan penambahan Sikament-NN dapat dilihat pada Tabel 5 dan pada gambar 2 serta gambar 3 .

Tabel 5. Hasil Pengujian Kuat Tekan Beton

\begin{tabular}{|c|c|c|c|c|c|c|}
\hline $\begin{array}{c}\% \\
\text { Sikament-NN }\end{array}$ & Benda Uji & $\begin{array}{c}\text { Berat } \\
\text { (g) }\end{array}$ & $\begin{array}{l}\text { Luas } \\
\left(\mathrm{cm}^{2}\right)\end{array}$ & $\begin{array}{c}\text { Beban } \\
(\mathbf{k N})\end{array}$ & $\begin{array}{c}\text { Kuat Tekan } \\
\left(\mathrm{kg} / \mathrm{cm}^{2}\right)\end{array}$ & $\begin{array}{c}\text { Kuat Tekan } \\
\text { Rata-rata } \\
\left(\mathrm{kg} / \mathrm{cm}^{2}\right)\end{array}$ \\
\hline \multirow{3}{*}{0} & I & 12680 & 176,79 & 520 & 29,99 & \multirow{3}{*}{27,49} \\
\hline & II & 12810 & 176,79 & 460 & 26,53 & \\
\hline & III & 12860 & 176,79 & 450 & 25,96 & \\
\hline \multirow{3}{*}{0,3} & I & 12,130 & 176,79 & 430 & 24,80 & \multirow{3}{*}{22,98} \\
\hline & II & 12,160 & 176,79 & 380 & 21,92 & \\
\hline & III & 12,195 & 176,79 & 385 & 22,21 & \\
\hline \multirow{3}{*}{0,8} & I & 12,420 & 176,79 & 440 & 25,38 & \multirow{3}{*}{23,26} \\
\hline & II & 12,310 & 176,79 & 365 & 21,05 & \\
\hline & III & 12,220 & 176,79 & 405 & 23,36 & \\
\hline \multirow{3}{*}{1,3} & I & 12510 & 176,79 & 650 & 37,49 & \multirow{3}{*}{35,18} \\
\hline & II & 12725 & 176,79 & 560 & 32,30 & \\
\hline & III & 12298 & 176,79 & 620 & 35,76 & \\
\hline \multirow{3}{*}{1,8} & I & 12870 & 176,79 & 700 & 40,38 & \multirow{3}{*}{38,65} \\
\hline & II & 12355 & 176,79 & 640 & 36,92 & \\
\hline & III & 12705 & 176,79 & 670 & 38,65 & \\
\hline \multirow{3}{*}{2,3} & I & 12371 & 176,79 & 600 & 34,61 & \multirow{3}{*}{33,45} \\
\hline & II & 12340 & 176,79 & 560 & 32,30 & \\
\hline & III & 12505 & 176,79 & 580 & 33,45 & \\
\hline
\end{tabular}




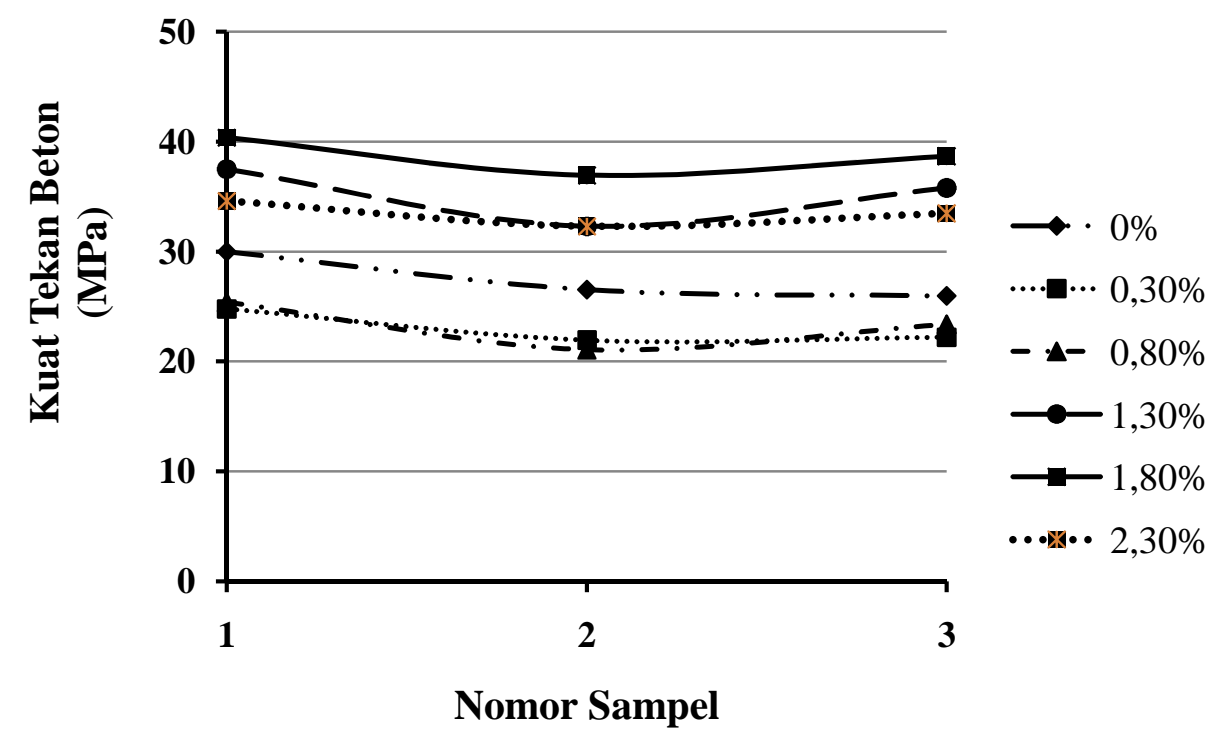

Gambar 2. Hasil Kuat Tekan Beton pada Benda Uji dengan penambahan variasi persentase Sikament-NN

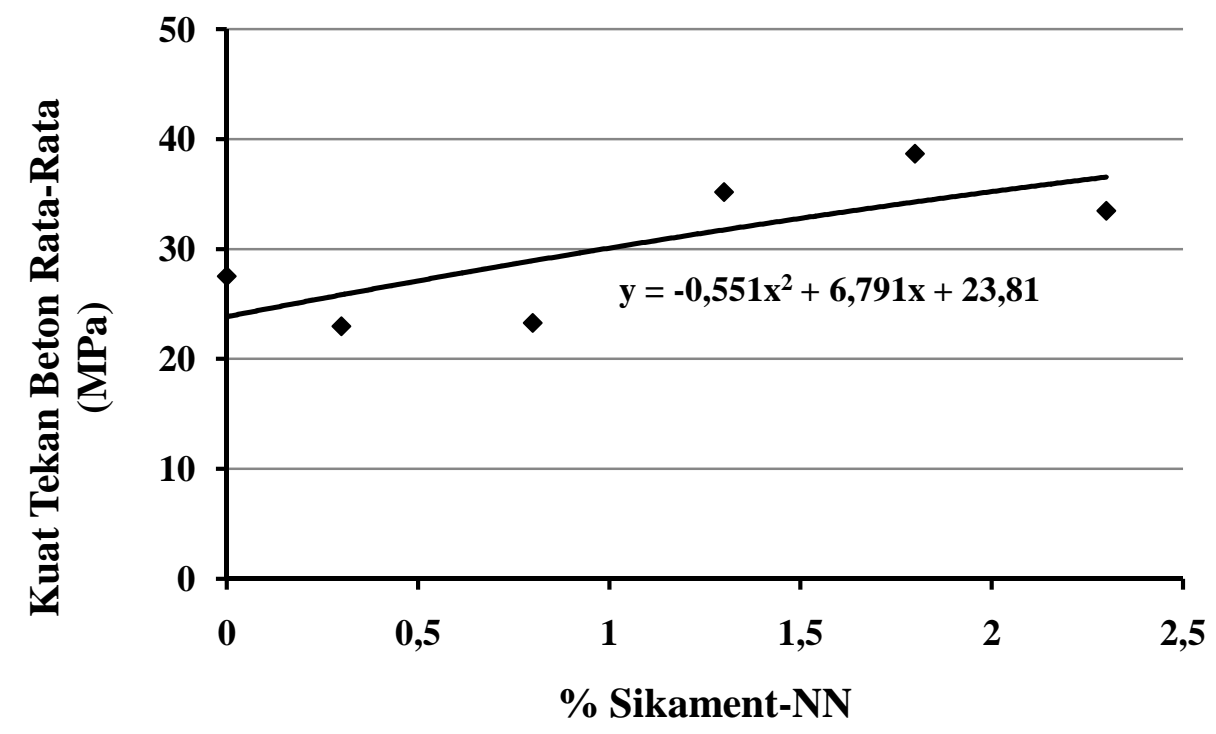

Gambar 3. Hubungan kuat tekan beton rata-rata dengan penambahan Sikament-NN

\section{Analysis of Variance - ANOVA}

Tabel rancangan perlakuan dengan notasi matematika dapat dilihat pada tabel 6 dan tabel analisis ragam dapat dilihat pada tabel 7.

Dari Tabel F dapat dilihat bahwa $\mathrm{F}^{0.05}$ Tabel $=3,11$ dan $\mathrm{F}^{0.01}$ Tabel $=5,06$, sedangkan $\mathrm{F}_{\text {hitung }}=33,17$. Karena $\mathrm{F}_{\text {hitung }}$ $>\mathrm{F}_{\text {Tabel}}$, maka dapat dinyatakan bahwa terdapat interaksi atau perlakuan yang sangat nyata antara kuat tekan beton dengan penambahan variasi SikamentNN. 
Tabel 6. Notasi Matematika

\begin{tabular}{|c|c|c|c|c|c|}
\hline \multirow{2}{*}{ No } & \multirow{2}{*}{$\begin{array}{c}\% \\
\text { Sikament-NN }\end{array}$} & \multicolumn{4}{|c|}{ Sampel } \\
\hline & & 1 & 2 & 3 & Sum \\
\hline 1. & 0 & 29,99 & 26,53 & 25,96 & $\sum_{\mathrm{i}-1} \mathrm{Y} 1_{\mathrm{j}}=82,48$ \\
\hline 2. & 0,3 & 24,80 & 21,92 & 22,21 & $\sum_{j-1} Y 2_{j}=68,93$ \\
\hline 3. & 0,8 & 25,38 & 21,05 & 23,36 & $\sum_{\mathrm{i}-1} \mathrm{Y} 3_{\mathrm{j}}=69,79$ \\
\hline 4. & 1,3 & 37,49 & 32,30 & 35,76 & $\sum_{j-1} \mathrm{Y}_{j}=105,55$ \\
\hline 5. & 1,8 & 40,38 & 36,92 & 38,65 & $\sum_{j-1} Y 5_{j}=115,95$ \\
\hline 6. & 2,3 & 34,61 & 32,30 & 33,45 & $\sum_{j-1} Y 6_{j}=100,36$ \\
\hline
\end{tabular}

Tabel 7. Hasil uji F dengan Menggunakan Kuat Tekan Beton

\begin{tabular}{ccccc}
\hline SK & DB & JK & KT & $\mathbf{F}_{\text {count }}$ \\
\hline Perlakuan & 5 & 643,30 & 128,66 & 33,17 \\
Galat percobaan & 12 & 46,55 & 3,88 & \\
Total & 17 & 689,85 & 132,54 & \\
\hline
\end{tabular}

\section{Pembahasan}

Pada penelitian ini digunakan agregat kasar dan agregat halus yang biasa digunakan di Provinsi Riau. Berdasarkan hasil pengujian pendahuluan material diperoleh bahwa agregat kasar dan agregat halus sesuai dengan persyaratan sebagai bahan campuran beton.

Hasil pengujian menunjukkan bahwa kuat tekan beton benda uji mengalami penurunan pada penambahan $0,3 \%$ dan $0,8 \%$ SikamentNN dibandingkan dengan benda uji tanpa penambahan Sikament-NN. Kuat tekan benda uji mengalami peningkatan setelah penambahan persentase $1,3 \%$ dan $1,8 \%$ Sikament-NN dan kembali mengalami penurunan pada penambahan $2,3 \%$ namun tetap lebih besar dari pada kuat tekan rencana.

Persamaan kuat tekan rata-rata yang diperoleh dengan variasi penambahan Sikament-NN sebesar $y=-0,551 x^{2}+6,791 x+23,81$.

Berdasarkan pengujian Analysis of Variance - ANOVA diperoleh bahwa $\mathrm{F}_{\text {hitung }}>\mathrm{F}_{\text {Tabel }}$, maka dapat dinyatakan bahwa terdapat interaksi atau perlakuan yang sangat nyata antara kuat tekan beton dengan penambahan variasi Sikament-NN. 


\section{E. KESIMPULAN}

Kesimpulan yang diperoleh adalah :

1. Kuat tekan beton pada benda uji lebih besar dibandingkan dengan kuat tekan rencana yaitu $\mathrm{f}_{\mathrm{c}}{ }^{\prime}=24,90$ $\mathrm{MPa}$ pada variasi penambahan Sikament-NN 0\%, 1,3\%, 1,8\% dan $2,3 \%$.

2. Nilai kuat tekan tertinggi diperoleh pada penambahan $1,8 \%$ SikamentNN yaitu sebesar 38,65 MPa.

3. pengujian Analysis of Variance ANOVA diperoleh $\mathrm{F}^{0.05}$ Tabel $=3,11$ $; \mathrm{F}^{0.01}$ Tabel $=5,06$ dan $\mathrm{F}_{\text {hitung }}=33,17$, karena $F_{\text {hitung }}>F_{\text {Tabel }}$ maka dapat dinyatakan bahwa terdapat interaksi atau perlakuan yang sangat nyata antara kuat tekan beton dengan penambahan variasi Sikament-NN.

\section{DAFTAR PUSTAKA}

Aprilianti S., Nadia, 2012, Analisis Pengaruh Beton dengan Bahan Admixture Naphtalene dan Polycarboxilate Terhadap Kuat Tekan Beton Normal, Jurnal Konstruksia, Volume 3 Nomor 2, April 2012:33 - 40 .

Nugraha P., Antoni, 2007, Teknologi Beton, Andi Offset, Yogyakarta.

PT. Sika Indonesia, 2011, Data Teknis Know-How From Site To Shelf.

Ramadhani K.C., Yanti G., Winayati, 2016, Analisis Kuat Tekan Beton Terhadap Variasi Persentase Bahan Tambah Sikament NN, Program Studi Teknik Sipil Universitas Lancang Kuning, Pekanbaru.

Yitnosumarto S., 1991, Percobaan Perancangan, Analisis Dan Interprestasinya, PT. Gramedia Pustaka Utama, Jakarta. 